\title{
Colonialism, capital, and ressentiment
}

\section{Franziska Cooiman}

Weizenbaum Institute, Germany/Roskilde University, Denmark

Joseph Vogl's new book, Capital and Ressentiment (2021), spans an analytical net between finance, the digital economy, its media platforms, and the structural populisms operating there. In the breadth of its perspective, the new book seamlessly follows its predecessors. ${ }^{1}$ Over six chapters, his 'brief theory of the present' weaves various contemporary societal analyses into a new picture whose strength lies in the emerging connections. A prefatory note says that the word 'and' in the title is subjected to a stress test (p. 7), and indeed it is these analyses around the 'and' that make Vogl's latest study so interesting: The financial industry is taking an increasingly central position and benefits from the emergence of the internet industry. Information is the most important resource of the financial and internet industries. The resulting information economy structures the public sphere, produces ressentiments, and can turn these affects into money. Ressentiment thus stabilizes financial and digital capitalism, functioning as a "product and productive force" (p. 8, emphasis added).

Vogl's perspective resembles that of a nomad, as described by Gilles Deleuze and Félix Guattari, who wanders through entire disciplines and levels of immanence in a way that leaves visible traces (Deleuze and Guattari, 1987). The resulting congenial overview of the history of science, economics, and media theory allows for a new understanding of the present and exposes its contingent trajectories. Three of his main points of reference are the empirical work of Philipp Staab (2019) on digital capitalism, Aaron Sahr (2017) on monetary theory, and Nick Srnicek (2016) on platform capitalism. Not all connections contribute equally to the viability of his analysis - for example, when talking about a 'polis of solution' (Morozov, 2014; Nachtwey and Seidl, 2020), which Vogl addresses as a new "normative order" (p. 101), only to devote a few paragraphs to it instead of systematically developing his point.

In the following, I would like to elaborate on two central analytical connections and one fundamental omission in Vogl's book. The first connection spans between finance and the internet industry. Digitization and in particular "electronic networks" have, Vogl argues, enabled an effective fusion of the financial and information economies, which brought about a rapid expansion of the financial sector and the hegemony of financial market capitalism (p. 7). To begin with, this is an important and plausible observation. The financial sector benefits

\section{Corresponding author:}

Franziska Cooiman, Weizenbaum Institute, Hardenbergstraße 32, 10623 Berlin. Germany.

Email: franziska.cooiman@wzb.eu. https://doi.org/10.2218/finsoc.v7i2.6634 
from developments in information technology and is thus able to expand its close-knit global capital network. Similarly, Vogl argues, "platform companies are now entering financial operations", in particular as they "create private payment and money systems" (p. 104). As an example, Vogl discusses Facebook's recently renamed Diem currency project. He sees this as an attempt to "close the circle between financialization, informatization, and controlling power, to relate the private occupation of sovereign powers to the economic order as a whole, and to perfect the transition from a government-controlled to a market-controlled financial system" (p.104). In Vogl's mind, whether it is the financial sector that embraces information technologies or the internet industry that forces its way into finance, both strengthen the hegemony of financial market capitalism

At this point, Vogl misses out on possible tensions between the incumbent financial industry and the emerging internet industry (Hendrikse, Bassens and Meeteren, 2018; Rothstein, 2021). In addition to symbiotic relationships and mimetic movements, there certainly are also frictions that could point to fault lines in the seemingly so solid power relations. The Facebook currency project illustrates such frictions: its founding members predominantly consist of venture capital firms and technology companies, while not a single traditional financial institution, such as a bank, is among them. Projects such as this one, therefore, aim to challenge the hegemony of the financial sector. Another example is the practice of venture capital firms listing startups directly on the stock exchange by means of a so-called direct listing instead of a traditional IPO, which banks would accompany. In this way, venture capital firms and their startups circumvent the high fees that banks collect in an IPO process and dry up one of incumbent finance's most important sources of income (Christophers, 2015). Finally, valuation debacles such as in the case of WeWork or Theranos also make visible the rifts that can open up between the 'normative orders' of the venture capital-driven internet industry and the traditional financial industry.

The second analytical axis spans between economics and politics. Vogl argues that the "fabrication of the current financial regime" cannot be grasped with the "dogmatic juxtaposition" of the pairs economy-politics or market-state (p. 21). Instead, "government functions and market-based modes of action have entered into a bi-polar internal relationship, defining an economic and financial system that deserves the title of regulatory capitalism" ( $p$. 22). The current financial regime thus structures an "immanent space in which sovereign powers, government actions, transactions, and market operations intertwine". At the same time, Vogl argues, it generates its own "rules and dependencies" in the process becoming a "fourth power", a "monetative" alongside legislative, executive, and judicial powers of government. Consequently, we can observe the transition from a "geopolitical to a geoeconomic order" and from a "government-driven to a market-driven financial system" ( $p$. 32). The reference to the growing political power of parademocratic financial institutions, such as central banks or development banks, is important. And to sharply observe their mode of operation and modes of action is no less significant. A fundamental feature of connecting lines, however, is that they lead in two directions. What is discussed in the political economy literature as the 'infrastructural power' of finance allocates power to financial actors in the political process and to political actors in the financial world (Braun, 2018; Braun and Gabor, 2020; Cooiman, 2021).

Vogl himself points to "the interpenetration of nation-state organs, international organizations and networks, private agencies, firms, and market processes" and a resulting "multilayered web of regulatory orders of varying density and scope" (p. 21). His analysis, however, focuses primarily on the power on the economic or market side. Two issues arise. First, albeit acknowledging the web-shaped nature of state-market relations, Vogl diagnoses 
the transformation from a geopolitical to a geoeconomic order, a government-driven to a market-driven financial system, hence reinstating the dogmatic juxtaposition he criticizes. His diagnosis also sounds very familiar to yesterday's debates over neoliberalism, which had found closure in acknowledging the agential role of the state in establishing and sustaining neoliberal order.

Second, and more importantly from a normative point of view, it is precisely the agency of state actors that demands attention. Focusing on issues where this agency surfaces, such as legal infrastructures, which result from political actors codifying economic power (Pistor, 2019), may have kept Vogl from ending with the dystopian outlook of "the ferment for a new prewar era" (p. 182).

In addition to these two lines of connection, I would like to take a closer look at one omission in Vogl's story: colonialism, racism, and its consequences. Although he mentions colonial history, racism, and regions of the Global South such as 'Africa' or 'Asia', he does so only in passing (pp. 118, 168, 107). By focusing on European and North American capitals and ressentiments, Vogl remains spatially and analytically wedded to the Global North.

His explanation begins in a world that would not exist without colonial exploitation and racialized hierarchy, exclusion, and privilege, not only in its historical emergence but also in its present mode of reproduction (Koddenbrock, Kvangraven and Sylla, 2020; Bhattacharyya, 2018; Patnaik and Patnaik, 2021). Capitalism's history is more than a sequence of pathdependent regimes of accumulation (see e.g., Fraser and Jaeggi, 2018), the latest of which Vogl describes. It is fundamentally shaped by colonialism, imperialism, and the racisms that proliferate on top of them. To insert a third axis into the analysis, in the spirit of a "colonial global economy' (Bhambra, 2020) and 'racial capitalism' (Bhattacharyya, 2018), would thus sharpen the view of drivers and dynamics of the present, in terms of its economic relations, affectual economies, and, crucially, the links between both.

For instance, Vogl's understanding of the postwar welfare states as emerging from "strong trade unions and banking regulation, capital and currency controls, defensive economic, fiscal and social policies, long-term investment and mass production" (p. 10) would have to be supplemented by recognition of colonial and imperial exploitations, extractions, and other forms of racialized dispossessions. As Gurminder Bhambra (2020: 11) puts it: "the state is only able to respond to local working class demands by drawing on resources from elsewhere and, at the same time, excluding those others from the distribution of resources". According to recent estimates by economist Utsa Patnaik (2020), Britain extracted an amount equalling $\$ 45$ trillion from India in the years 1765 to 1938 , while after the war Britain devalued its currency to significantly lower the value of its immense debt burden towards India (Bhambra, 2020: 10), allowing it to invest in its own economy and welfare state. This is not to say that for all European states, post-colonial drain amounted to an equally large amount; it is just to give an example of the colonial and racialized foundations of contemporary capitalism.

Vogl's omission implies the common and convenient misunderstanding of European states as "being nations and having empire", instead of being imperial states (Bhambra, 2020: 6). In other words, imperial histories are regarded as a side fact, not core to the structural analysis of contemporary capitalist orders. Reproducing this misunderstanding comes with political implications. The "right to have rights within a state" tends to be associated with the ability to "demonstrate historical belonging to the nation" (Bhambra, 2020: 12), which is determined by colonialism and remains racialized even to this day (Bhambra and Holmwood, 2018). The failure to acknowledge that the historical political communities of most European states were much broader prepares the ground for authoritarian politics fueled by entitlement and ressentiment. 
A colonial-analytical axis touches upon the capital side of Vogl's argument and that of ressentiment. According to Vogl, ressentiments thrive through

a circulating lack or shortage and the consequent production of scarcity, which is the basis of capitalist market systems [... and] refers to what has always been 'snatched away'. The other always has what no one has [...]. Ressentiment suffers from the theft of what has never been possessed; it is afflicted by a covetous lack of desire, by an inaccessible, suspected, and imputed abundance in the other that does not exist. (p.165)

If ressentiment is ignited by what has always already been taken away and which no one has ever possessed, such a desire for the presumed fullness of the Other reflects not only the logic of capitalist scarcity but also a historical claim on domination. In Eva von Redecker's (2020b: 34) words, it is the propertized oppression or "dominion" of the past that presupposes the "phantom possession" of the present, i.e., the painful lack of what one thinks one can rightfully dispose of (Redecker, 2020a: 32). The phantom possession in whiteness (or masculinity) is "the excess accumulation of entitlement brought up against the horizon of the possible freedom of oppressed others" (Redecker, 2020b: 35). Imperial domination fantasies come to light as ressentiment on media platforms and are exploited politically and economically. After removing institutional anchors, such as direct forms of colonial exploitation, these phantom possessions intensify at the level of identity, which is addressed on media platforms.

Redecker historizices affectual dispositions along the lines of propertization and dominion, combining an ideological with a materialist account and thus offers an understanding of the patterns of distribution of ressentments, which Vogl merely brushes over. The material roots of affects, according to von Redecker, are neither deterministic nor do they work on an individual level. Historically flawed social relations manifest in individual affectual dispositions and "relegate[s] subjects into different ontological spheres; they are marked as having or as being phantom possession, as entitled to appropriate or as appropriable" (Redecker, 2020b: 53).

Vogl emphasizes that the emergence of ressentiments cannot be reduced to material disadvantages and proposes that in capitalist societies the "interlocking of promises of participation and relations of production enable and direct an affective interpretation of power relations, the perception of divergences and competitions, and thus the efficacy of comparative mechanisms" (p. 164). His argumentation, however, remains abstract and does not recognize how participation promises and power relations are racialized and distributed along the lines of imperial and colonial histories. In this respect, including an account of racism and colonial histories would not only situate the emergence of the financial regime in global history, but at the same time, weave another strand into the understanding of the contemporary affect economy and its role in reproducing capitalism today.

In spite of this omission, Vogl's observation that the ressentiments circulating on media platforms function as both a product and productive force at the same time and are thus vital for capitalist survival is sharp, and can serve as a starting point for studies that combine materialist analyses of the political economy with accounts of racism (and sexism) - as suggested by von Redecker - to grasp the capitalist dynamic of the present. Capital and Ressentiment bustles with intellect, breaks with disciplinary boundaries, and addresses important questions about the intertwining of politics and economics in present times. Only sometimes, instead of following his great intellectual leaps, I want to ask Joseph Vogl, 'slow down, take a closer look!' 


\section{Notes}

1. This review first appeared in German on Soziopolis.de, March 25, 2021. Page numbers refer to the original German edition (Vogl, 2021). All direct quotes are review author's own translation, except for those taken from Chapter 6, which were translated by Neil Solomon for Polity Press. The English translation of the entire book will be published by Polity next year (Vogl, 2022).

\section{References}

Bhambra, G.K. (2020) Colonial global economy: Towards a theoretical reorientation of political economy. Review of International Political Economy, https://doi.org/ 10.1080/09692290.2020.1830831

Bhambra, G.K. and Holmwood, J. (2018) Colonialism, postcolonialism and the liberal welfare state. New Political Economy, 23(5): 574-87.

Bhattacharyya, G. (2018) Rethinking Racial Capitalism: Questions of Reproduction and Survival. Lanham, MD: Rowman \& Littlefield.

Braun, B. (2018) Central banking and the infrastructural power of finance: The case of ECB support for repo and securitization markets. Socio-Economic Review, https://doi.org/10.1093/ser/mwy008

Braun, B. and Gabor, D. (2020) Central banking, shadow banking and infrastructural power. In: Mader, P., Mertens, D. and Van der Zwan, N. (eds.) The Routledge International Handbook of Financialization. London: Routledge, 241-52.

Christophers, B. (2015) Value models: Finance, risk, and political economy. Finance and Society, 1(2): 1-22.

Cooiman, F. (2021) Veni vidi VC: The backend of the digital economy and its political making. Review of International Political Economy, https://doi.org/10.1080/09692290.2021.1972433

Deleuze, G. and Guattari, F. (1987) A Thousand Plateaus: Capitalism and Schizophrenia. Minneapolis: University of Minnesota Press.

Fraser, N. and Jaeggi, R. (2018) Capitalism: A Conversation in Critical Theory. Medford, MA: Polity.

Hendrikse, R., Bassens, D. and van Meeteren, M. (2018) The Appleization of finance: Charting incumbent finance's embrace of FinTech. Finance and Society, 4(2): 159-80.

Koddenbrock, K., Kvangraven, I.H. and Sylla, N.S. (2020) Beyond financialisation: The need for a longue durée understanding of finance in imperialism. OSF Preprints, https://doi.org/10.31219/ osf.io/pjt7x

Morozov, E. (2014) To Save Everything, Click Here: Technology, Solutionism and the Urge to Fix Problems That Don't Exist. London: Penguin.

Nachtwey, O. and Seidl, T. (2020) The solutionist ethic and the spirit of digital capitalism. SocArXiv, https://doi.org/10.31235/osf.io/sgjzq

Patnaik, U. and Patnaik, P. (2021) Capital and Imperialism: Theory, History, and the Present. New York: Monthly Review Press.

Pistor, K. (2019) The Code of Capital, How the Law Creates Wealth and Inequality. Princeton, NJ: Princeton University Press.

Redecker, Eva von (2020a) Revolution Für Das Leben: Philosophie Der Neuen Protestformen. Frankfurt am Main: S. Fischer.

Redecker, Eva von (2020b) Ownership's shadow: Neoauthoritarianism as defense of phantom possession. Critical Times, 3(1): 33-67

Rothstein, S.A. (2021) Toward a discursive approach to growth models: Social blocs in the politics of digital transformation. Review of International Political Economy, https://doi.org/

10.1080/09692290.2021.1895278 
Sahr, A. (2017) Keystroke-Kapitalismus: Ungleichheit Auf Knopfdruck. Hamburg: Hamburger Edition. Srnicek, N. (2016) Platform Capitalism. Cambridge: Polity Press.

Staab, P. (2019) Digitaler Kapitalismus: Markt und Herrschaft in der Ökonomie der Unknappheit. Berlin: Suhrkamp Verlag.

Vogl, J. (2021) Kapital und Ressentiment: Eine kurze Theorie der Gegenwart. München: C.H. Beck. Vogl, J. (2022) Capital and Ressentiment, translated by N. Solomon. Cambridge: Polity. 